\title{
Sunscreens' UV Filters Risk for Coastal Marine Environment Biodiversity: A Review
}

\author{
Samuele Caloni ${ }^{1}$, Tiziana Durazzano ${ }^{1}$, Giada Franci ${ }^{1}$ and Letizia Marsili ${ }^{1,2, *(D)}$ \\ 1 Department of Physical, Earth and Environmental Sciences, University of Siena, Via Mattioli, 4, \\ 53100 Siena, Italy; samuele.caloni@student.unisi.it (S.C.); tiziana.durazzano@student.unisi.it (T.D.); \\ giada.franci@student.unisi.it (G.F.) \\ 2 Department of Physical, Earth and Environmental Sciences, Inter-University Center of Cetacean \\ Research (CIRCE), University of Siena, Via Mattioli, 4, 53100 Siena, Italy \\ * Correspondence: letizia.marsili@unisi.it; Tel.: +39-0577-232083
}

Citation: Caloni, S.; Durazzano, T.; Franci, G.; Marsili, L. Sunscreens' UV Filters Risk for Coastal Marine Environment Biodiversity: A Review. Diversity 2021, 13, 374. https:/ / doi.org/10.3390/d13080374

Academic Editor: Bert W. Hoeksema

Received: 6 July 2021

Accepted: 10 August 2021

Published: 12 August 2021

Publisher's Note: MDPI stays neutral with regard to jurisdictional claims in published maps and institutional affiliations.

Copyright: (c) 2021 by the authors. Licensee MDPI, Basel, Switzerland. This article is an open access article distributed under the terms and conditions of the Creative Commons Attribution (CC BY) license (https:// creativecommons.org/licenses/by/ $4.0 /)$.

\begin{abstract}
Considering the rapid growth of tourism in recent years and the acknowledgement that exposure to solar UV radiation may cause skin cancer, sunscreens have been widely used by beachgoers in recent decades. UV filters contained in sunscreens, however, were recently identified as emerging pollutants in coastal waters since they accumulate in the marine environment with different adverse effects. In fact, exposure to these components was proven to be toxic to most invertebrate and vertebrate marine species. Some UV filters are linked to the production of significant amounts of reactive oxygen species (ROS), such as hydrogen peroxide, and the release of inorganic micronutrients that may alter the status of coastal habitats. Bioaccumulation and biomagnification have not yet been fully addressed. This review highlights recent progress in research and provides a comprehensive overview of the toxicological and ecotoxicological effects of the most used UV filters both on the abiotic and biotic compartments in different types of coastal areas, to gain a better understanding of the impacts on coastal biodiversity.
\end{abstract}

Keywords: sunscreens; UV filters; nanoparticles; coastal areas; coral reef; ecotoxicology

\section{Introduction}

During the last decade, tourism has seen massive growth and is among the economic sectors expected to experience constant development in the future. It was estimated that by 2035 , the rate of global tourism will increase by $179 \%$, and is set to generate substantial anthropic stress on natural environments [1]. In fact, in 2017, the Mediterranean sea alone attracted over 267 million international tourists [2]. Water environments are at high risk, and plenty of research has been devoted to studying them: fragile balances regulate these environments, particularly in the coastal areas, for they are very rich in biodiversity and the ecosystem services provided by these areas sustain half of the planet population [3]. Coastal tourism, and the related recreational activities, have led to a massive use of photoprotective personal care products (PCPs), which are highly and widely recommended to prevent skin damage from sun exposure [4-6], resulting in a direct input from swimming and bathing (non-point sources). These inputs, together with industrial wastewater discharges (point sources) [7-9], are capable of starting decay processes, irreversible at times [6]. In fact, coastal tourism is acknowledged as a source of impact on shallow-water marine habitats [1], as well as lakes and rivers [10,11]. Unfortunately, recent data about the global annual production of these PCPs are lacking. Last available data from a market study in 2005 estimated a 10,000 tons of sunscreens global production per year [12]. This means that nowadays there is a gap in judging the threat currently posed to the environment. Nonetheless, it was evaluated that, during in-water activities, at least $25 \%$ of sunscreens and PCPs applied to the skin get washed off [13]. A study carried out in France estimated that a sample of 3000 beachgoers applied, on average, $52.5 \mathrm{~kg}$ of sunscreen per day, releasing 
$15.7 \mathrm{~kg}$ of it into the water [14]. Since the widespread use of photoprotective PCPs, UV filters contained in sunscreens have become emerging contaminants in various environments. Only in recent years, the scientific community has started studying and investigating the causes and the effects of their accumulation in different ecosystems [4,15-17].

\subsection{Sunscreen Definition}

Sunscreen lotions are defined as PCPs containing UV filters, substances whose main function is to reflect, to refract, and to dissipate the wavelengths of sunlight considered harmful to human skin (UVA 320-400 nm and UV-B 280-320 nm). These lotions are designed for external application and the UV filters contained in the general PCP formula can be distinguished into organic and inorganic [18].

\subsubsection{Organic Filters}

Organic filters (or chemical) are synthesized substances, which include the derivatives of cinnamic acid such as ethylhexyl methoxycinnamate (EHMC), benzophenones (BPs) such as the commonly used benzophenone-3 (BP-3), salicylates such as ethylhexyl salicylate (OCS), benzoyl derivatives such as diethylamino hydroxybenzoyl hexyl benzoate (DHHB), and butyl methoxydibenzoylmethane (BMDBM). These compounds usually have single or multiple aromatic structures, sometimes conjugated with carbon-carbon double bonds and carbonyl moieties, able to attenuate the transmission of energetic solar photons that reach the surface of the Earth [6]. These molecules typically get to an excited state when hit by UV radiations and release the energy as fluorescence or heat, and, in this way, are able to dissipate a part of it and transform the rest into a non-harmful wavelength for the skin [4].

\subsubsection{Inorganic Filters}

Inorganic (also referred to as physical or mineral) filters provide filtering action against sunlight via two mechanisms: (1) the crystals refract and scatter a significant amount of the incoming radiation, and (2) the molecules themselves get to an excited state and then de-excite the same way as organic filters. These cycles of excitement and de-excitement entail a collateral photocatalytic activity, which is capable of producing reactive oxygen species (ROS), such as $\mathrm{O}_{2}{ }^{-\bullet}, \mathrm{HO}^{\bullet}$, and $\mathrm{H}_{2} \mathrm{O}_{2}$ [19]. There are only two mineral filters widely approved and used around the world: titanium dioxide $\left(\mathrm{TiO}_{2}\right)$ and zinc oxide $(\mathrm{ZnO})$, which can be used in both micrometric $\left(\mathrm{TiO}_{2}\right.$ and $\left.\mathrm{ZnO}\right)$ and nanometric form $\left(\mathrm{n}-\mathrm{TiO}_{2}\right.$ and $\left.\mathrm{n}-\mathrm{ZnO}\right)$. In the latter, the particles can be referred to as engineered nanoparticles (NPs or ENPs) and, if they are made of $\mathrm{TiO}_{2}$, they are often coated with inert compounds to avoid undesired chemical reactions capable of skin damage [20]. The coating often has one or two layers: the innermost, which is made of an inert material, e.g., alumina $\left(\mathrm{Al}_{2} \mathrm{O}_{3}\right)$, aluminum hydroxide $\left(\mathrm{Al}(\mathrm{OH})_{3}\right)$ or silica $\left(\mathrm{SiO}_{2}\right)$ [21], and the outer, e.g., silicone, which is optional and used to give hydrophobic properties to improve the blending capacities of $\mathrm{TiO}_{2}$ [22].

\subsubsection{Other Compounds}

Apart from UV filters, sunscreen lotions contain other ingredients such as preservatives, emulsifiers, colorants, foams, and perfumes [5].

\section{Abiotic Compartment}

The most analyzed matrices to evaluate the behavior of UV filters are waters, sediments, and SML (surface microlayer). Water samples are used to evaluate the water solubility of the substances examined and the relative concentrations [23-27], while sediments and SML are used because they are more suitable for the identification of lipophilic compounds released into the environment $[4,5,28]$.

The measurement of the production of ROS species can be carried out directly or indirectly: the direct way involves spectrometry, setting the reading of the sample at a specific wavelength characteristic of each chemical species; while the indirect way predicts the determination, spectrometric [22] or chromatographic [29], of the oxidized amount of a 
compound acting as a "trap" for ROS, i.e., 2,3-bis(2-methoxy-4-nitro-5-sulfophenyl)-2Htetrazolium-5-car-boxanilide (XTT) [22] and furfuryl alcohol (FFA) [29].

\subsection{Mineral Filters Behavior in Water}

$\mathrm{TiO}_{2}$ and $\mathrm{ZnO}$ are among the most employed particles in sunscreens. These two raw materials, depending on the size used (micrometric or nanostructured), show different behaviors in water. It was evaluated that micrometric mineral filters may be released into seawater by up to $49 \%$ of the quantity used, meaning they are extremely washable [14], due to their hydrophilicity. As per the nanostructured UV filters, they can be released in the environment in variable amount from $8 \%$ up to $72 \%$, with the cosmetic formula having a large influence on the leaching rate (mean \pm SD: $45 \pm 33 \%$ ) [30].

Once leached into the water, they undergo further modifications since the external silicone layer can be easily degraded in slightly acidic $(\mathrm{pH}=5)$ or slightly alkaline $(\mathrm{pH}=9)$ waters [22]. As time passes and the surface becomes more and more degraded, NPs can enter into suspension from $5 \%$ to over $30 \%$ of the total amount of sunscreen dispersed in water [21,31]. The presence of organic matter in water represents an important contribution for the stabilization of the particles of $\mathrm{nTiO}_{2}$, which, once dispersed in water, may remain isolated or form aggregates together with macromolecules capable of forming complexes (e.g., humic acids) $[32,33]$ that endure in the environment. Moreover, there is evidence that salinity and $\mathrm{pH}$ play a role in leading NPs to aggregate and to descend the water column until they reach the bottom, where they may lay and eventually sediment [21].

The main negative side of inorganic UV filters is their ability to transfer the absorbed energy to other surrounding molecules, causing ROS formation. These oxygen compounds, characterized by a high reactivity, cause oxidative stress in organisms exposed to higher concentrations. In particular, the photocatalytic activity of $\mathrm{TiO}_{2}$ is also linked to the size of the particles used in the formulation: the microparticles have a moderate reactivity, which does not require countermeasures beyond the respect of a maximum percentage in the formulation; nanoparticles, on the other hand, are much more reactive and therefore require a coating $[21,34,35]$.

\subsection{Organic UV Filters and Derivatives Behavior in Water}

Organic UV filters tend to be more concentrated on the SML and could, therefore, influence the availability of sunlight for photosynthetic organisms, a phenomenon which would be especially harmful in areas where barrier reefs are present $[13,36]$. This happens because some organic UV filters have photocatalytic activity, a feature that makes them co-responsible for the overproduction of ROS in aquatic environments $[29,37]$. The main responsible organic UV filters for ROS production in aquatic environment are octinoxate (EHMC), octocrylene (OCR), 4-aminobenzoic acid (PABA), and 2-ethylhexyl 4(dimethylamino)benzoate (OD-PABA). In this context, benzophenones (particularly BP-3 and BP-8) and ethylhexyl salicylate (OCS) are more suitable because they seem to be incapable of forming singlet oxygen or other ROS when exposed to light [29]. In a well-lit environment, sunscreens can also undergo photodegradation, often generating less toxic compounds than the original UV filter: benzophenone derivatives showed, in laboratory studies, a modest genotoxic potential if present in concentrations of $>250 \mathrm{ng} / \mathrm{L}$, comparable to those that they are found in crowded parts of the coast or areas with low water exchange [38-40]. Other UV filters, such as OD-PABA, EHMC and iso-amylmethoxycinnamate (IAMC), are overall less toxic, especially if exposed to intense illumination due to their higher photolability, when compared to the previous case $[40,41]$.

\subsection{Release of Inorganic Nutrients and Metals in the Aquatic Environment}

There is proof that the introduction of sunscreens into shallow-water environments lead to the release of heavy metals, purportedly present within the lotion as leftovers and production process debris, and micronutrients, such as $\mathrm{NO}_{3}{ }^{-}, \mathrm{NH}_{4}{ }^{+}$, and $\mathrm{PO}_{4}{ }^{3-}$, which are residuals derived from the degradation of some organic compounds and linked to 
events of eutrophication and anomalous algal growth [4,42]. The photoprotective PCPs formulations contain not only water and sunscreens, but also a vast set of substances that are dispersed into the environment. Elements that play important biological roles, for example, $\mathrm{Fe}, \mathrm{Cu}, \mathrm{N}$, and $\mathrm{P}$, or are highly toxic to most organisms, such as $\mathrm{Pb}$ and $\mathrm{Cd}$, can also be released $[31,38]$. Conservative simulations carried out for a typical Mediterranean beach showed an increase, compared to background concentrations, of close to $20 \%$ for Ti and $5 \%$ for Al. All the other elements taken into consideration also had a small increase, mostly less than $0.1 \%$ [31].

\section{Biotic Compartment}

The toxicity of various UV filters contained in sunscreens, both organic and inorganic, on marine organisms varies considerably depending on the UV filter and organism physiology. Many studies emphasized biological and toxicological responses, which may affect survival, behavior, growth, development, and reproduction, that were observed at various trophic levels. Coral reefs will be discussed separately in Section 4 as they are unique environments highly exposed to both climate change and human activities.

Table 1 summarizes recent studies carried out on the exposure of various organisms to UV filters and the effects of these exposures.

Table 1. Effects of various UV filters from different studies.

\begin{tabular}{|c|c|c|c|c|}
\hline UV Filter(s) & Organism(s) & Exposure Conditions & Effects & Reference \\
\hline $\begin{array}{c}\text { 4-MBC } \\
\text { BP-3 } \\
\text { BP-4 } \\
\text { EHMC }\end{array}$ & $\begin{array}{c}\text { Mediterranean mussel } \\
\text { (Mytilus galloprovincialis), } \\
\text { sea urchin } \\
\text { (Paracentrotus lividus) }\end{array}$ & $\mathrm{EC}_{50}$ & $\begin{array}{l}\text { EHMC and 4-MBC toxicity } \\
\text { assessed from } 4-5 \mathrm{mg} / \mathrm{L}, \\
\text { followed by BP-3 and } \\
\text { finally BP-4 }\end{array}$ & [43] \\
\hline $\mathrm{n}-\mathrm{TiO}_{2}$ & $\begin{array}{l}\text { Mediterranean mussel } \\
\text { (Mytilus galloprovincialis) }\end{array}$ & From 0.05 to $5 \mathrm{mg} / \mathrm{L}$ for $24 \mathrm{~h}$ & $\begin{array}{l}\text { Cellular damage NRR in } \\
\text { hemocytes and digestive } \\
\text { glands; stimulated } \\
\text { glutathione-S-transferase } \\
\text { (GST) }\end{array}$ & [44] \\
\hline $\mathrm{n}-\mathrm{TiO}_{2}$ & $\begin{array}{c}\text { Mediterranean mussel } \\
\text { (Mytillus galloprovincialis) }\end{array}$ & From 2.8 to $280 \mu \mathrm{g} / \mathrm{L}$ for $24 \mathrm{~h}$ & $\begin{array}{l}\text { Adaptive response in gills at } \\
28 \mu \mathrm{g} / \mathrm{L} \text {; oxidative stress and } \\
\text { neurotoxicity over } 280 \mu \mathrm{g} / \mathrm{L}\end{array}$ & [45] \\
\hline $\mathrm{n}-\mathrm{TiO}_{2}$ & $\begin{array}{l}\text { Marine abalone (Haliotis } \\
\text { diversicolor supertexta) }\end{array}$ & $\begin{array}{l}\text { Acute toxicity stress: from } \\
0.1 \text { to } 10 \mathrm{mg} / \mathrm{L} \text { for } 96 \mathrm{~h}\end{array}$ & $\begin{array}{l}\text { Oxidative stress: SOD } \\
\text { increased }(1 \mathrm{mg} / \mathrm{L}), \mathrm{GSH} \\
\text { decreased }(1 \mathrm{mg} / \mathrm{L}), \mathrm{LPO} \\
\text { dose-dependent increase }\end{array}$ & [46] \\
\hline $\mathrm{n}-\mathrm{TiO}_{2}$ & $\begin{array}{c}\text { Lungworm } \\
\text { (Arenicola marina) }\end{array}$ & $\begin{array}{c}\text { Sub-lethal OECD/ASTM } \\
1990 \text { acute toxicity test }\end{array}$ & $\begin{array}{l}\text { Decrease in casting rate; } \\
\text { increase in cellular damage } \\
\text { (NRR); DNA damage } \\
\text { in coelomocytes }\end{array}$ & [47] \\
\hline $\mathrm{n}-\mathrm{ZnO}$ & $\begin{array}{c}\text { Sea urchin } \\
\text { (Paracentrotus lividus) }\end{array}$ & $\begin{array}{l}\text { 21-day exposure via food to } \\
\text { reach } 10 \mathrm{mg} \mathrm{Zn} / \mathrm{kg} \text { food }\end{array}$ & $\begin{array}{l}\text { Damages to immune cells ( } 33 \% \\
\text { of damaged nucleus); } \\
\text { transmissible effects to } \\
\text { offspring ( } 75.5 \% \text { of } \\
\text { malformed larvae) }\end{array}$ & [48] \\
\hline
\end{tabular}


Table 1. Cont.

\begin{tabular}{|c|c|c|c|c|}
\hline UV Filter(s) & Organism(s) & Exposure Conditions & Effects & Reference \\
\hline 4-MBC & $\begin{array}{c}\text { Senegalese sole } \\
\text { (Solea senegalensis) }\end{array}$ & $\begin{array}{l}\text { Mortality and growth } \\
\text { assessment } 96 \mathrm{~h} \text { egg } \\
\text { exposure from } 0.235 \text { to } \\
0.935 \mathrm{mg} / \mathrm{L} \text {; biochemical } \\
\text { markers from } 0.068 \text { to } \\
0.360 \mathrm{mg} / \mathrm{L}\end{array}$ & $\begin{array}{l}\text { Induced mortality and } \\
\text { malformations in a } \\
\text { dose-response manner; } \\
\text { reduced growth with } \\
\text { increasing concentrations; } \\
\text { increased activity of AChE on } \\
\text { larvae exposed to } 0.085 \mathrm{mg} / \mathrm{L} ; \\
\text { significantly lower LDH } \\
\text { activity ( } \mathrm{p} \text { b 0.05); swimming } \\
\text { behavior was affected by } \\
\text { 4-MBC at low concentrations. }\end{array}$ & [49] \\
\hline $\begin{array}{l}\text { BP-1 } \\
\text { BP-2 } \\
\text { BP-3 } \\
\text { BP-4 } \\
\text { BP-7 } \\
\text { BP-8 }\end{array}$ & $\begin{array}{l}\text { Marine bacterium } \\
\text { (Photobacterium } \\
\text { phosphoreum) and } \\
\text { planktonic crustacean } \\
\text { (Daphnia magna) }\end{array}$ & $\begin{array}{l}\mathrm{EC}_{50} \text { protocol and } \\
\text { QSAR modelling }\end{array}$ & $\begin{array}{l}\text { Toxicity evaluated for } \\
\text { both species }\end{array}$ & {$[50]$} \\
\hline PBSA & $\begin{array}{c}\text { Rainbow trout } \\
\text { (Oncorhynchus mykiss) }\end{array}$ & $\begin{array}{c}21 \text { and } 42 \text { days; from } 1 \text { to } \\
1000 \mu \mathrm{g} / \mathrm{L}\end{array}$ & $\begin{array}{l}\text { Increased activity of } \\
\text { P450 cytochromes }\end{array}$ & [51] \\
\hline $\begin{array}{l}\text { 4-MBC } \\
\text { BP-3 } \\
\text { BMDBM } \\
\text { EHMC } \\
\text { OCR } \\
\text { HMS }\end{array}$ & $\begin{array}{c}\text { Ciliate } \\
\text { (Tetrahymena thermophila) }\end{array}$ & $\mathrm{IC}_{50}$ & $\begin{array}{l}\text { 4-MBC, BP-3 and BMDBM } \\
\text { could significantly inhibit the } \\
\text { activity of the MXR system, } \\
\mathrm{IC}_{50} \text { values of } 4-\mathrm{MBC}, \mathrm{BP}-3, \\
\text { and BMDBM were } 23.54,40.59 \text {, } \\
\text { and } 26.37 \mathrm{lM}\end{array}$ & [52] \\
\hline $\begin{array}{c}\text { BP } \\
\text { 2-HBP } \\
\text { BP-3 } \\
\text { BP-4 }\end{array}$ & $\begin{array}{l}\text { Bioluminescent bacterium } \\
\text { (Vibrio fischeri) in vitro and } \\
\text { zebrafish (Danio rerio) } \\
\text { larvae in vitro }\end{array}$ & $\begin{array}{c}\mathrm{EC}_{50}, \mathrm{SOS} / \mathrm{umu} \text { assay and } \\
\text { yeast estrogen screen assay } \\
\text { (YES assay) }\end{array}$ & $\begin{array}{l}\text { Luminescent bacteria toxicity, } \\
\text { expressed as logEC } \mathrm{C}_{50} \\
\text { increased with the lipophilicity } \\
\left(\log \mathrm{K}_{\mathrm{OW}}\right) \text { of BP-derived UV } \\
\text { filters; estrogenic activity in } \\
\text { dose-effect relationship. } V \text {. } \\
\text { fischeri toxicity order is BP-3 }> \\
2-\mathrm{HBP}>\mathrm{BP}>\mathrm{BP}-4\end{array}$ & [53] \\
\hline $\begin{array}{l}\mathrm{BP}-1 \\
\mathrm{BP}-3\end{array}$ & $\begin{array}{c}\text { Green alga } \\
\text { (Chlamydomonas reinhardtii) }\end{array}$ & $\begin{array}{c}\text { Response surface } \\
\text { methodologies (RSM) }\end{array}$ & $\begin{array}{l}\text { Exposure to the combined BP-1 } \\
\text { and BP-3 negatively affected } \\
\text { cell growth and pigments } \\
\text { production, with } \\
\text { dose-dependent inhibition, } \\
\text { affecting the } \\
\text { photosynthesis process }\end{array}$ & [54] \\
\hline $\begin{array}{c}\text { BP-1 } \\
\text { BP-2 } \\
\text { 3-BC } \\
\text { Et-PABA }\end{array}$ & $\begin{array}{l}\text { Fathead minnow } \\
\text { (Pimephales promelas) }\end{array}$ & $\begin{array}{l}\text { 14-day BP-1 from } 8.9 \text { to } \\
4919.4 \mu \mathrm{g} / \mathrm{L} ; \mathrm{BP}-2 \text { from } 10.3 \\
\text { to } 8782.9 \mu \mathrm{g} / \mathrm{L} ; 3 \mathrm{BC} \text { from } 8.7 \\
\text { to } 952.5 \mu \mathrm{g} / \mathrm{L} \text { e Et-PABA } \\
\text { from } 6.9 \text { to } 4394 \mu \mathrm{g} / \mathrm{L}\end{array}$ & $\begin{array}{l}\text { Induction of vitellogenin: 3-BC } \\
\text { from } 3 \mu \mathrm{g} / \mathrm{L} \text { and BP-2 from } \\
1.2 \mathrm{mg} / \mathrm{L} \text { caused feminization } \\
\text { in male fish, alteration of } \\
\text { gonads in male and female } \\
\text { fish, and decrease in fertility } \\
\text { and reproduction }\end{array}$ & [55] \\
\hline
\end{tabular}


Table 1. Cont.

\begin{tabular}{|c|c|c|c|c|}
\hline UV Filter(s) & Organism(s) & Exposure Conditions & Effects & Reference \\
\hline BP-3 & Zebrafish (Danio rerio) & $\begin{array}{l}\text { Fish and embryos were } \\
\text { exposed for } 14 \text { days and } \\
120 \mathrm{~h} \text { post-fertilization, } \\
\text { respectively, to } 2.4-312 \mu \mathrm{g} / \mathrm{L} \\
\text { and } 8.2-438 \mu \mathrm{g} / \mathrm{L} \mathrm{BP}-3 \text {. }\end{array}$ & $\begin{array}{l}\text { BP-3 was partly transformed to } \\
\text { BP-1 and both compounds } \\
\text { were accumulated in adult fish; } \\
\text { BP-3 exposure led to similar } \\
\text { alterations of gene expression } \\
\text { in both adult fish and } \\
\text { eleuthero embryos with } \\
\text { antiandrogenic activity }\end{array}$ & [56] \\
\hline BP-3 & $\begin{array}{l}\text { Japanese medaka } \\
\text { (Oryzias latipes) }\end{array}$ & $\begin{array}{l}14 \text { days from } 0 \text { to } 90 \mu \mathrm{g} / \mathrm{L} \text {. } \\
\text { First generation eggs (F1) } \\
\text { reproduced were counted } \\
\text { and further exposed up to } \\
\quad 30 \mu \mathrm{g} / \mathrm{L} \text { of BP-3 }\end{array}$ & $\begin{array}{l}\text { After } 14 \text { days, plasma } \\
\text { concentrations of testosterone } \\
\text { (T) significantly increased in } \\
\text { male fish. The } 17-\beta \text {-estradiol } \\
\text { (E2) to T (E2/T) ratio showed } \\
\text { significant decreases in both } \\
\text { male and female fish during } \\
28 \text { day exposure; daily average } \\
\text { egg reproduction per female } \\
\text { was significantly reduced at } \\
26 \mu g / L \text { of BP-3; hatchability } \\
\text { of F1 eggs was not affected }\end{array}$ & [57] \\
\hline $\begin{array}{l}\text { BP-3 } \\
\text { EHMC } \\
\text { IAMC } \\
\text { OD-PABA } \\
\text { OCR } \\
\text { 4-MBC }\end{array}$ & $\begin{array}{c}\text { Green alga } \\
\text { (Scenedesmus vacuolatus) }\end{array}$ & $\mathrm{EC}_{50}$ & $\begin{array}{l}\text { BP-3 showed } 43 \text {-fold higher } \\
\text { toxicity than theoretically } \\
\text { predicted. BP-3 and IAMC } \\
\text { seem to have a more specific } \\
\text { mode of action on algal cells }\end{array}$ & {$[40]$} \\
\hline $\begin{array}{l}\text { BMDBM } \\
\text { EHMC } \\
\text { OCR }\end{array}$ & $\begin{array}{c}\text { Non-biting midge } \\
\text { (Chironomus riparius), } \\
\text { oligochaete (Lumbriculus } \\
\text { variegatus), and snails } \\
\text { (Melanoides tuberculata and } \\
\text { Potamopyrgus antipodarum). }\end{array}$ & $\begin{array}{c}56 \text { days (L. variegatus) or } \\
28 \text { days (Chironomus riparius, } \\
\text { M. tuberculata, P. antipodarum) } \\
\text { sediment test }\end{array}$ & $\begin{array}{l}\text { EHMC caused a toxic effect on } \\
\text { reproduction in both snails } \\
\text { with lowest observed effect } \\
\text { concentrations (LOEC) of } \\
0.4 \mathrm{mg} / \mathrm{kg} \text { (Potamopyrgus } \\
\text { antipodarum) and } 10 \mathrm{mg} / \mathrm{kg} \\
\text { (Melanoides tuberculata). } \\
\text { BDMDM and OCR showed no } \\
\text { effects on any of the } \\
\text { tested organisms }\end{array}$ & [58] \\
\hline $\begin{array}{l}\text { EHMC } \\
\text { OCR } \\
\text { BMDBM }\end{array}$ & $\begin{array}{l}\text { Planktonic crustacean } \\
\quad(\text { Daphnia magna) }\end{array}$ & $\begin{array}{c}\mathrm{EC}_{10}, \mathrm{EC}_{25}, \text { and } \mathrm{EC}_{50} \\
\mathrm{EHMC} \text { up to } 80.0 \mu \mathrm{g} / \mathrm{mL} ; \\
\mathrm{OCR} \text { and BMDBM up to } \\
640.0 \mu \mathrm{g} / \mathrm{mL} ;\end{array}$ & $\begin{array}{l}\text { EHMC, OCR, and BMDBM } \\
\text { highly toxic at low } \\
\text { concentration ( }>1 \mu \mathrm{g} / \mathrm{mL}) \text { and } \\
\text { resulted in immobilization } \\
\text { higher than } 25 \% \text {; } \\
\text { immobilization reached more } \\
\text { than } 90 \% \text { at concentrations of } \\
40 \mu \mathrm{g} / \mathrm{mL} \text {; EC } 50 \text { values for } \\
\text { EHMC, OCR, and BMDBM } \\
\text { were } 2.73,3.18 \text {, and } \\
1.95 \mu \mathrm{m} / \mathrm{mL}, \text { respectively, } \\
\text { indicating that OCR had the } \\
\text { lowest toxic effect on Daphnia; } \\
\text { reduction of toxic effects in the } \\
\text { mixtures of the three UV-filters, } \\
\text { caused by antagonistic action } \\
\text { of the components }\end{array}$ & [59] \\
\hline
\end{tabular}


Table 1. Cont.

\begin{tabular}{|c|c|c|c|c|}
\hline UV Filter(s) & Organism(s) & Exposure Conditions & Effects & Reference \\
\hline $\mathrm{n}-\mathrm{TiO}_{2}$ & $\begin{array}{l}\text { Cyanobacterium } \\
\text { (Anabaena variabilis) }\end{array}$ & $\begin{array}{l}24 \mathrm{~h} \text { to } 6 \text { days from } 0.5 \text { to } \\
250 \mathrm{mg} / \mathrm{L}\end{array}$ & $\begin{array}{l}\text { Reduced } \mathrm{N} \text { fixation activity, } \\
\text { growth rate, toxicity time, and } \\
\text { dose-dependency }\end{array}$ & {$[60]$} \\
\hline $\mathrm{n}-\mathrm{TiO}_{2}$ & $\begin{array}{l}\text { Fathead minnow } \\
\text { (Pimephales promelas) }\end{array}$ & $\begin{array}{l}\text { Exposed to } 2 \mathrm{ng} / \mathrm{g} \text { and } \\
10 \mathrm{mg} / \mathrm{g} \text { body weight. } \\
\text { Challenged with fish } \\
\text { bacterial pathogens, } \\
\text { Aeromonas hydrophila or } \\
\text { Edwardsiella ictaluri }\end{array}$ & $\begin{array}{c}\text { Fish mortality during bacterial } \\
\text { challenge with Aeromonas } \\
\text { hydrophila and Edwardsiella } \\
\text { ictalurid; reduced neutrophil } \\
\text { phagocytosis of } A \text {. hydrophila; } \\
\text { significant } \\
\text { histopathological alterations }\end{array}$ & {$[61]$} \\
\hline $\mathrm{n}-\mathrm{TiO}_{2}$ & $\begin{array}{l}\text { European sea bass } \\
\text { (Dicentrarchus labrax) }\end{array}$ & 7 days, $1 \mathrm{mg} / \mathrm{L}$ & Chromosomal alteration & [62] \\
\hline $\mathrm{n}-\mathrm{TiO}_{2}$ & $\begin{array}{l}\text { Marine scallop } \\
\text { (Chlamys farreri) }\end{array}$ & 14 days, $1 \mathrm{mg} / \mathrm{L}$ & $\begin{array}{c}\text { Elevated superoxide dismutase } \\
\text { (SOD), catalase (CAT) } \\
\text { activities, and } \\
\text { malondialdehyde (MDA) } \\
\text { contents, increased } \\
\text { acetylcholinesterase (AChE) } \\
\text { activities; histopathological } \\
\text { alterations in gills and } \\
\text { digestive gland (dysplastic } \\
\text { and necrosis) }\end{array}$ & {$[63]$} \\
\hline $\begin{array}{l}\mathrm{n}-\mathrm{TiO}_{2} \\
\mathrm{n}-\mathrm{ZnO}\end{array}$ & $\begin{array}{c}\text { Diatoms (Skeletonema } \\
\text { marinoi, Thalassiosira } \\
\text { pseudonana), green alga } \\
\text { (Dunaniella tertiolecta), and } \\
\text { Haptophyta alga } \\
\text { (Isochrysis galbana) }\end{array}$ & $\begin{array}{l}24 \text { and } 96 \mathrm{~h} \text { from } 0.10 \text { to } \\
\qquad 1000 \mu \mathrm{g} / \mathrm{L}\end{array}$ & $\begin{array}{c}\mathrm{n}-\mathrm{TiO}_{2} \text { did not affect the } \\
\text { growing rate, } \mathrm{n}-\mathrm{ZnO} \\
\text { depressed growth in all species }\end{array}$ & {$[64]$} \\
\hline $\mathrm{n}-\mathrm{ZnO}$ & $\begin{array}{c}\text { Diatoms } \\
\text { (Thalassiosira pseudonana, } \\
\text { Chaetocerus gracilis, } \\
\text { Phaedacttylum tricornutum) }\end{array}$ & $72 \mathrm{~h}$, from 10 to $80 \mathrm{mg} / \mathrm{L}$ & $\begin{array}{c}\text { Growth stopped in } T \text {. } \\
\text { pseudonana and C. gracilis; } \\
\text { growth rate inversely } \\
\text { proportional to NP } \\
\text { concentration in } P \text {. tricornutum; } \\
\text { Zn bioaccumulation killed } \\
\text { T. pseudonana }\end{array}$ & [65] \\
\hline $\mathrm{n}-\mathrm{ZnO}$ & $\begin{array}{c}\text { Diatoms (Skeletonema } \\
\text { costatum and Thalassiosia } \\
\text { pseudonana), crustaceans } \\
\text { (Tigriopus japonicus and } \\
\text { Elasmopus rapax), and } \\
\text { medaka fish } \\
\text { (Oryzias melastigma) }\end{array}$ & $\mathrm{IC}_{50}$ & $\begin{array}{l}\mathrm{n}-\mathrm{ZnO} \text { toxic towards algae; } \\
\mathrm{ZnO} \text { toxic towards crustaceans; } \\
\text { up-regulation of SOD and MT. } \\
\text { Toxicity attributed mainly to } \\
\text { dissolved } \mathrm{Zn} \text { ions }\end{array}$ & {$[66]$} \\
\hline $\mathrm{n}-\mathrm{ZnO}$ & $\begin{array}{c}\text { Green alga (Dunaliella } \\
\text { tertiolecta), bioluminescent } \\
\text { bacterium (Vibrio fischeri), } \\
\text { brine shrimp } \\
\text { (Artemia salina) }\end{array}$ & $\begin{array}{l}V \text {. fischeri bioluminescence } \\
\text { test for } 5 \text {, to } 30 \text { min from } 0.3 \\
\text { to } 40 \mathrm{mg} / \mathrm{L} ; D \text {. tertiolecta } \\
\text { algal growth test } 24,48 \text { and } \\
72 \mathrm{~h} \text { from } 0.1 \text { to } 10 \mathrm{mg} / \mathrm{L} ; A \text {. } \\
\text { salina acute toxicity at } \\
24-96 \mathrm{~h} \text { from } 10 \text { to } 100 \mathrm{mg} / \mathrm{L} \text {, } \\
\text { A. salina chronic exposure for } \\
14 \text { days from } 0.03 \text { to } \\
0.5 \mathrm{mg} / \mathrm{L}\end{array}$ & $\begin{array}{l}\mathrm{ZnO} \text { 14-day chronic exposure } \\
\text { of } A \text {. salina significant } \\
\text { inhibition of vitality and body } \\
\text { length }\left(\mathrm{EC}_{50} 14 \mathrm{~d} 0.02 \mathrm{mg}\right. \\
\mathrm{Zn} / \mathrm{L}) . \mathrm{ZnO} \text { NPs were more } \\
\text { toxic towards algae }\left(\mathrm{EC}_{50}\right. \\
2.2 \mathrm{mg} \mathrm{Zn} / \mathrm{L}) \text {, but relatively } \\
\text { less toxic towards bacteria } \\
\left(\mathrm{EC}_{50} 17 \mathrm{mg} \mathrm{Zn} / \mathrm{L}\right) \text { and } \\
\text { crustaceans }\left(\mathrm{EC}_{50} 96 \mathrm{~h} 58 \mathrm{mg}\right. \\
\mathrm{Zn} / \mathrm{L})\end{array}$ & [67] \\
\hline
\end{tabular}


Table 1. Cont.

\begin{tabular}{|c|c|c|c|c|}
\hline UV Filter(s) & Organism(s) & Exposure Conditions & Effects & Reference \\
\hline $\begin{array}{l}\text { OD-PABA } \\
\text { OCR }\end{array}$ & $\begin{array}{c}\text { Haptophyta alga (Isochrysis } \\
\text { galbana), Mediterranean } \\
\text { mussel (Mytilus } \\
\text { galloprovincialis), and sea } \\
\text { urchin (Paracentrotus } \\
\text { lividus) in early stage }\end{array}$ & $\begin{array}{l}\text { I. galbana } 72 \mathrm{~h} \text { to } 2 \text { and } \\
90 \mathrm{ng} / \mathrm{L}, \text { M. galloprovincialis } \\
\text { and P. lividus } 48 \mathrm{~h} \mathrm{EC}_{50}\end{array}$ & $\begin{array}{l}\text { OCR was the more toxic } \\
\text { compound for P. lividus; } \\
\text { OD-PABA caused a severe } \\
\text { negative effect on both } M \text {. } \\
\text { galloprovincialis and I. galbana }\end{array}$ & [68] \\
\hline $\mathrm{n}-\mathrm{TiO}_{2}$ & $\begin{array}{l}\text { Mediterranean mussel } \\
\text { (Mytilus galloprovincialis) }\end{array}$ & $96 \mathrm{~h}$ from 1 to $100 \mu \mathrm{g} / \mathrm{L}$ & $\begin{array}{l}\text { Lysosomal and oxidative } \\
\text { stress; decreased transcription } \\
\text { of antioxidant and } \\
\text { immune-related genes; } \\
\text { decreased lysosomal } \\
\text { membrane stability and } \\
\text { phagocytosis; increased } \\
\text { oxyradical production and } \\
\text { transcription of antimicrobial } \\
\text { peptides; pre- } \\
\text { apoptotic processes }\end{array}$ & [69] \\
\hline $\begin{array}{l}\text { Sunscreen } \\
\text { containing BP-3, } \\
\text { sunscreen } \\
\text { containing } \\
\mathrm{TiO}_{2}\end{array}$ & $\begin{array}{c}\text { Clownfish } \\
\text { (Amphiprion ocellaris) }\end{array}$ & $\begin{array}{l}97 \mathrm{~h} \text { from } 0 \mathrm{mg} / \mathrm{L}, 1 \mathrm{mg} / \mathrm{L}, \\
3 \mathrm{mg} / \mathrm{L}, 10 \mathrm{mg} / \mathrm{L}, 30 \mathrm{mg} / \mathrm{L} \\
\text { and } 100 \mathrm{mg} / \mathrm{L}\end{array}$ & $\begin{array}{l}\text { Exposure level of } 100 \mathrm{mg} / \mathrm{L} \\
\text { of } \mathrm{BP}-3 \text { containing sunscreen } \\
\text { led to } 25 \% \text { death and } 100 \% \\
\text { disrupted swimming behavior } \\
\text { by the end of the } 97-\mathrm{h} \text { testing } \\
\text { period. } 100 \% \text { of the animals } \\
\text { failed to feed over the first } 49 \mathrm{~h} \\
\text { of testing } \\
\mathrm{TiO}_{2} \text { sunscreen at } 100 \mathrm{mg} / \mathrm{L} \\
\text { had } 6.7 \% \text { mortality, swimming } \\
\text { behavior was disrupted during } \\
\text { the first } 25 \text { h of testing ( } 26.7 \% \\
\text { abnormal movement), animals } \\
\text { recovered well over the } \\
\text { remainder of the testing period } \\
\text { (out to } 97 \mathrm{~h} \text { ) }\end{array}$ & {$[70]$} \\
\hline 4-MBC & $\begin{array}{c}\text { Japanese clam } \\
\text { (Ruditapes philippinarum) }\end{array}$ & $\begin{array}{c}\text { 0, 1, 10,100 } \mu \mathrm{g} / \mathrm{L} \text { over a } \\
\text { 7-day period followed by a } \\
\text { 3-day depuration period } \\
\text { (total } 10 \text { days) }\end{array}$ & $\begin{array}{c}\text { Assessed mortality reached up } \\
\text { to } 100 \% \text { at concentration of } \\
100 \mu \mathrm{g} / \mathrm{L} . \mathrm{LC} 50 \text { value of } \\
7.71 \mu \mathrm{g} / \mathrm{L} \text {-was derived }\end{array}$ & [71] \\
\hline 4-MBC & $\begin{array}{c}\text { Copepod } \\
\text { (Tigriopus japonicus) }\end{array}$ & $\begin{array}{l}\text { Exposed to three different } \\
\text { salinity conditions }(20,30, \\
\text { and } 40 \mathrm{ppt} \text { ) prior to exposure } \\
\text { to } 0,1 \text {, and } 5 \mu \mathrm{g} / \mathrm{L} \text { for } \\
\text { multiple generations (F0-F3) }\end{array}$ & $\begin{array}{l}\text { Environmentally relevant } \\
\text { concentrations of 4-MBC had } \\
\text { toxic effects on T. japonicus. } \\
\text { Higher salinity levels increased } \\
\text { the lethal, developmental, and } \\
\text { reproductive toxicities of } \\
\text { 4-MBC in T. japonicus }\end{array}$ & {$[72]$} \\
\hline
\end{tabular}


Table 1. Cont.

\begin{tabular}{cccc}
\hline UV Filter(s) & Organism(s) & Exposure Conditions & Effects \\
\hline BP-3 & & & HMS and OCR were the most \\
BEMT & & A. salina 48 h exposure at 0, & $\begin{array}{c}\text { A. salina at high concentrations } \\
\text { toxic, followed by BMDBM, on }\end{array}$ \\
BMDBM & Brine shrimp & $0.02,0.2,2,20,200$, and & DHHB affected metabolic \\
MBBT & (Artemia salina) and green & $2000 \mu \mathrm{g} / \mathrm{L} ;$ Tetraselmis spp. & activity of green algae at \\
OCS & algae (Tetraselmis spp.) & 7-day exposure at 10,100, & $100 \mu \mathrm{g} / \mathrm{L}$. BEMT, DBT, EHT, \\
DHHB & & and $1000 \mu \mathrm{g} / \mathrm{L}$ & and MBBT had no effects, even \\
DBT & & & at high concentrations \\
EHT & & & (2 mg/L). \\
HMS & & & \\
OCR & & & \\
\hline
\end{tabular}

Legend: benzophenone (BP) and its derivatives (2-HBP, BP-1, BP-2, BP-3, BP-4, BP-7, and BP-8); 3-benzylidene camphor (3-BC); octyl methoxycinnamate or ethylhexyl methoxycinnamate (EHMC); octocrylene (OCR); butyl methoxydibenzoylmethane or avobenzone (BMDBM); homosalate (HMS); iso-amylmethoxy-cinnamate (IAMC); 4-methylbenzylidene camphor (4-MBC); ethyl-4-aminobenzoate (Et-PABA); 2-ethylhexyl 4-dimethylaminobenzoate (OD-PABA); 2-phenylbenzimidazole-5-sulfonic acid (PBSA); bis-ethylhexyloxyphenol methoxyphenyl triazine (BEMT); methylene bis-benzotriazolyl tetramethylbutylphenol (MBBT); 2-ethylhexyl salicylate (OCS); diethylaminohydroxybenzoyl hexyl benzoate (DHHB); diethylhexyl butamido triazone (DBT); ethylhexyl triazone (EHT); nanostructured titanium dioxide $\left(\mathrm{n}-\mathrm{TiO}_{2}\right)$; nanostructured zinc oxide $(\mathrm{n}-\mathrm{ZnO})$.

It should be noted that most of these experiments were performed in laboratory settings and some of the UV filters were tested in isolation. Moreover, the concentrations used as stressor are usually higher than those observed in the environment.

\subsection{Toxicity of Organic UV Filters}

Samplings of wild Mytilus edulis and Mytilus galloprovincialis in ten sites along the French Atlantic and Mediterranean coasts from June to November 2008 showed accumulation of EHMC, OCR, and OD-PABA, highlighting how these concentrations significantly increased with the rising air temperature in summer and recreational pressure, although they also depended on the geomorphological structure of the sampling sites [74]. Studies carried out in the Hong Kong coastal area showed that the occurrence of these compounds was linked to the level of anthropogenic activities $[75,76]$. To validate patterns and the occurrence of PCPs in coastal sites impacted by recreational activities, diurnal variations (mirroring variations in recreational activities) as well as the tourist season [77] must be taken into consideration when writing monitoring protocols. In mussels, diurnal variations in OCR were observed, with the lowest concentrations recorded in the morning and then increasing throughout the day [26]. An alarming fact about organic UV filters is their diffusion in the planet's waters, wherein some of these compounds can be indicated as ubiquitous contaminants in the oceans: in a study conducted on marine water between the Pacific and the Atlantic Ocean and the Arctic Sea noted the presence, in each sample, of four UV filters (BP-3, OCR, BMDBM, and EHMC). The least polluted samples of the 12 organic UV filters tested were those of Shantou and Chaozhou (5 OUVs each), two cities in southern China near the mouth of the Han river, while the most polluted ones came from Hong Kong, in whose waters all 12 of the compounds analyzed were found [23]. Organic UV filters were reported as present in Arctic waters, far away from anthropogenic sources, and it's been hypothesized that these molecules were transported there by major oceanic currents from the conveyor belt [23].

The benthic community seems to be the most impacted by the presence of PCPs, since hydrophobic UV filters accumulate in the sediment phase [24], but the presence of UV filters may also enhance the spread of viral infection on both benthic and pelagic organisms [13]. At present, studies performed on the general formula or with a combination of UV filters are scarce both for the human body [78] and the environment [16]. Moreover, some organic UV filters seem to have estrogenic effects, but their activity and interactions in mixtures are largely unknown [55,79]. In particular, laboratory studies seemed to show that BP-3 showed anti-androgenic activities in zebrafish (Danio rerio) and Japanese medaka (Oryzias latipes) [56,57]. 
The analysis of biological tissues is used to identify bioaccumulation or biomagnification of organic UV filters along the food chain. Organic UV filters seem to accumulate with patterns similar to PCBs, highly persistent pollutants, [80] with the potential to reach marine mammals [81]. In a laboratory experiment performed on swamp crayfish (Procambarus clarkii), five organic UV filters (BP-3, 4-MBC, OCR, EHMC, and HMS) were tested for bioaccumulation and both 4-MBC and OCR showed accumulation in fecal matter, while EHMC and HMS showed the highest bioaccumulation factors [82]. In a natural environment, the presence of organic UV filters was ubiquitous in Lebranche mullet (Mugil liza) samples taken in the highly urbanized Guanabara Bay (Rio de Janeiro, Brazil) and data suggested an estimated daily intake in humans, via diet, from 0.3 to $15.2 \mathrm{ng}$ of UV filters $(\mathrm{kg} / \mathrm{body}$ weight). Therefore, UV filters might pose a hazard to human health as well [83]. To date, few data are available regarding the bioaccumulation and biomagnification processes, even if bioaccumulation has been detected $[26,84]$. This suggests that further evaluation must be undertaken to gain knowledge on the fate of these compounds along the trophic chain.

\subsection{Toxicity of Inorganic UV Filters}

As concerns the biotic field, particularly important is the tendency of inorganic UV filters to move vertically within the water column, starting from superficial layers, depending on surface charge, particle shape and size, and the $\mathrm{pH}$ and ionic strength of the water. The main problem, from a biological point of view, is that the suspended NPs can be captured by filtering organisms directly in the water column and, if not, will otherwise settle on the bottom and be taken up by detritivore organisms [85]. Studies carried out on the bivalve species Mytilus galloprovincialis showed the ability of the nano- $\mathrm{TiO}_{2}$ to generate a moderate oxidative stress at concentrations of $0.2 \mathrm{mg} / \mathrm{L}$. The stress was measured as the destabilization of the lysosomal membranes of hemocytes and digestive gland cells, and as an increase in the activity of the GST (glutathione-S-transferase) and catalase enzymes [44]. NPs, especially $n-\mathrm{TiO}_{2}$, are strongly suspected of being bio-available and potentially gatherable by living organisms, unveiling a biomagnification phenomenon along the trophic chain $[86,87]$.

In highly contaminated areas, their interaction with other pollutants may also be taken into consideration. A study performed in artificial seawater linked an antagonistic immune response towards 2,3,7,8-TCDD to the presence of $n-\mathrm{TiO}_{2}$ in European sea bass (Dicentrarchus labrax) after 7 days in vivo exposure, suggesting that $\mathrm{n}-\mathrm{TiO}_{2}$ negatively influenced immune response induced by 2,3,7,8-TCDD in the spleen [88].

Zinc oxide, on the other hand, can, once released into the environment, cause very serious damage to ecosystems because it is highly toxic to bacteria and to marine invertebrates [89]. Studies on populations of the planktonic crustacean (Daphnia magna) fed with microalgae (Pseudokirchneriella subcapitata) exposed to different concentrations of $\mathrm{ZnO}$ showed an important reduction in the reproductive rate of the D. magna population [90]. These data are particularly alarming since the presence of $\mathrm{ZnO}$ may lead to the shrinking of planktonic organisms at the lowest levels of the trophic web, potentially causing a "cascade effect" within the whole ecosystem [64].

\section{Toxicity on Coral Reef}

Barrier reefs are unique ecosystems that, in recent years, have been threatened by increasingly frequent bleaching events. A bleaching event refers to the loss of symbiotic zooxanthellae hosted within scleractinian corals, often causing the death of the whole coral and therefore a loss of biodiversity in the ecosystem. It is thought that up to $10 \%$ of all coral reefs on the planet are menaced by these events [13]. Latent infections are common in symbiotic zooxanthellans [91], but a link was established between the weakening of coral due to exposition to sunscreen and the occurrence of viral infections, suggesting that the presence of PCPs, especially BP-3 and BP-8, could be a joint cause [13,91,92]. For example, BP-3 exceeded the threshold values by over $20 \%$ in hard corals (Acropora sp. and A. pulchra) in Hong Kong beaches located near snorkeling spots. It should be noted that 
these two compounds were detected widely and frequently at high concentrations in most of the sampled locations, causing larval deformity and mortality [93]. BP-3 is so far a ubiquitous presence in coastal seawater, sediment, and coral tissue, as also determined from sampling at sites around Oahu, Hawaii [94]. Taking into consideration the official data of the UNWTO, it was evaluated that $10 \%$ of the total sunscreen used is used in barrier reef tropical areas, and these data raise consistent concerns for the conservation of these endangered environments. Even so, relatively few studies have been conducted to identify environmental concentrations and potential toxicity of organic and inorganic UV filters $[13,23,36,94,95]$. Overall, there is a strong need to improve our understanding of the in situ concentrations of UV filters and preservatives, as well as their individual and combined effects. The environmentally measured concentrations are generally significantly lower than the nominal concentrations used in the laboratory to assess toxicity, but co-effects with other parameters may be crucial to assess risks for these compounds. Recently, it was discovered that mostly organic filters, such as BP-3, showed exacerbated adverse effects in the light [96], confirming that the concentration itself may not be the only parameter to consider. The assessment of risk should include biotic parameters (e.g., sensitivities, life stages of coral, metabolic capacities focus on both the host and symbionts) as well as abiotic parameters (e.g., solar irradiation, presence of other pollutants, and water temperature). Furthermore, adult corals were proven to accumulate and metabolize BPs during exposure in laboratory [92], but these effects have not yet been fully evaluated.

Concerning inorganic UV filters, uncoated $\mathrm{ZnO}$ induced severe bleaching and stimulated a microbial enrichment in the seawater that surrounds the corals [97]. Moreover, the maximum photosynthetic efficiency $(\mathrm{Fv} / \mathrm{Fm})$ of symbiotic zooxanthellae in scleractinian coral (Stylophora pistillata) when exposed to $90 \mu \mathrm{g} / \mathrm{L}$ of $\mathrm{ZnO}$ for 35 days, was reduced by $38 \%$ as compared to the control [98]. This clearly shows that $\mathrm{ZnO}$ is not an environmentally friendly compound and that its impact should be carefully evaluated.

In contrast, $\mathrm{TiO}_{2}$ coated with alumina and dimethicone and $\mathrm{TiO}_{2}$ modified with manganese caused minimal alterations in symbiotic interactions and did not cause bleaching, thus making it more eco-friendly than $\mathrm{ZnO}$ [97]. Alongside the direct impact on corals, UV filters also seem to pose a significant threat to reef biota, suggesting population and colony decline, as well as behavioral changes, for some common inhabitants of the reefs [13,36].

The studies taken into consideration are synthesized in Table 2.

Table 2. Effects of various UV filters on corals and reef biota.

\begin{tabular}{|c|c|c|c|c|}
\hline UV Filter(s) & Organism(s) & Exposure Conditions & Effects & Reference \\
\hline $\mathrm{ZnO}$ & $\begin{array}{l}\text { Acropora spp. } \\
\text { coral nubbins }\end{array}$ & 24 and $48 \mathrm{~h}$, up to $6.3 \mathrm{mg} / \mathrm{L}$ & $\begin{array}{c}67 \% \text { coral nubbins } \\
\text { surface bleached }\end{array}$ & [97] \\
\hline $\begin{array}{c}\text { BMDBM 2\% } \\
\text { BP-3 6\% } \\
\text { EHMC 6\% } \\
\text { OCR 6\% } \\
\text { OCS 5\% } \\
\text { 4-MBC 3\% } \\
\text { Butylparaben } \\
0.5 \% \\
\text { and commercial } \\
\text { sunscreens }\end{array}$ & $\begin{array}{c}\text { Acropora spp. } \\
\text { coral nubbins, } \\
\text { Stylophora pistillata and } \\
\text { Millepora complanata }\end{array}$ & $\begin{array}{l}18,48 \text { and } 96 \mathrm{~h} \text {, final } \\
\text { concentrations of } 10,33,50, \\
\text { and } 100 \mu \mathrm{L} / \mathrm{L}\end{array}$ & $\begin{array}{l}\text { Sunscreen even in very low } \\
\text { quantities (i.e., } 10 \mu \mathrm{L} / \mathrm{L} \text { ) } \\
\text { resulted in the release of large } \\
\text { amounts of coral mucus } \\
\text { (composed of zoo-xanthellae } \\
\text { and coral tissue) within } \\
18-48 \mathrm{~h} \text { and complete } \\
\text { bleaching of hard corals } \\
\text { within } 96 \mathrm{~h}\end{array}$ & [13] \\
\hline
\end{tabular}


Table 2. Cont.

\begin{tabular}{|c|c|c|c|c|}
\hline UV Filter(s) & Organism(s) & Exposure Conditions & Effects & Reference \\
\hline BP-3 & $\begin{array}{l}\text { Stylophora pistillata } \\
\text { (larval form) }\end{array}$ & $\begin{array}{l}\text { PB-3 } \mathrm{EC}_{50} \text { and } \mathrm{LC}_{50} \text {, with } \\
\text { different light exposure ( } 8 \mathrm{~h} \\
\text { in the light, } 8 \mathrm{~h} \text { in the dark, a } \\
\text { full diurnal cycle of } 24 \mathrm{~h}, \\
\text { beginning at 08:00 in } \\
\text { daylight and darkness from } \\
\text { 18:00 in the evening until } \\
\text { 08:00 } \mathrm{h} \text { the next day, and a } \\
\text { full } 24 \mathrm{~h} \text { in darkness), at } \\
0.00001,0.0001,0.001,0.01, \\
0.1 \text { and } 1 \mathrm{mM}\end{array}$ & $\begin{array}{l}\text { BP-3 transformed planulae } \\
\text { from a motile state to a } \\
\text { deformed and sessile } \\
\text { condition, showing } \\
\text { genotoxicant, skeletal, and } \\
\text { endocrine disruptor activity. } \\
\text { BP-3 effects exacerbated in } \\
\text { the light }\end{array}$ & [96] \\
\hline $\begin{array}{c}\text { ZnO } \\
\text { Ethylparaben } \\
\text { Butylparaben } \\
\text { TDSA } \\
\text { DTS } \\
\text { EHT } \\
\text { BMDBM } \\
\text { OCR }\end{array}$ & Stylophora pistillata & $\begin{array}{c}35 \text { days: } \mathrm{ZnO} \text { from } 10 \text { to } \\
1000 \mu \mathrm{g} / \mathrm{L}, \mathrm{UV} \text { filters from } 10 \\
\text { to } 5000 \mu \mathrm{g} / \mathrm{L} \text {, preservatives } \\
\text { (Ethylparaben and } \\
\text { Butylparaben) from } 0.1 \mathrm{a} \\
1000 \mu \mathrm{g} / \mathrm{L}\end{array}$ & $\begin{array}{l}\mathrm{ZnO} \text { reduced photosynthetic } \\
\text { efficiency Fv/Fm by } 38 \% \text {, no } \\
\text { adverse effects on the other UV } \\
\text { filters tested up to the } \\
\text { concentration corresponding } \\
\text { to their water solubility limit. } \\
\text { Butylparaben decreased the } \\
\mathrm{Fv} / \mathrm{Fm} \text { by } 25 \% \text { at the highest } \\
\text { concentration of } 100 \mu \mathrm{g} / \mathrm{L}\end{array}$ & [98] \\
\hline $\begin{array}{l}\text { BP-1 } \\
\text { BP-3 } \\
\text { BP-4 } \\
\text { BP-8 }\end{array}$ & $\begin{array}{l}\text { Pocillopora damicornis, } \\
\text { Seriatopora caliendrum }\end{array}$ & $\begin{array}{l}\text { 7-12 days from } 0.1 \text { to } \\
1000 \mu \mathrm{g} / \mathrm{L} .<1000 \mu \mathrm{g} / \mathrm{L} \\
\text { (S. caliendrum nubbins) }\end{array}$ & $\begin{array}{l}\text { No bleaching was observed in } \\
\text { the } P \text {. damicornis larval tests, } \\
\text { while bleaching was observed } \\
\text { in the } P \text {. damicornis nubbin } \\
\text { tests. Overall, BP-1 and BP- } 8 \\
\text { were more toxic to the two } \\
\text { tested species than BP-3 and } \\
\text { BP- } 4 \text {, which matches the } \\
\text { relative bioaccumulation } \\
\text { potential of the four BPs }(\mathrm{BP}-8 \\
>\mathrm{BP}-1 \approx \mathrm{BP}-3>\mathrm{BP}-4)\end{array}$ & [92] \\
\hline $\begin{array}{c}\text { HMS } 13 \% \\
\text { BP-3 6\% } \\
\text { OCR 5\% } \\
\text { OCS 5\% } \\
\text { BMDBM 3\% }\end{array}$ & $\begin{array}{c}\text { Flatworm (Convolutriloba } \\
\text { macropyga); pulse corals } \\
\text { (Xenia sp.); glass anemones } \\
\text { (Aiptasia spp.); Diatoms } \\
\text { (Nitzschia spp.) }\end{array}$ & $\begin{array}{l}\text { Flatworms: } 72 \mathrm{~h} \text { from } 0.1 \text { to } \\
1 \mathrm{~mL} / \mathrm{L} \text {; pulse corals: } 72 \mathrm{~h} \text {, } \\
1 \mathrm{~mL} \text { in } 3.8 \mathrm{~L} \text { seawater; glass } \\
\text { anemones: } 7 \text { days from } 0.1 \text { to } \\
1 \mathrm{~mL} / \mathrm{L} \text {; diatoms: } 72 \mathrm{~h} 1 \mathrm{~mL} \\
\text { on } 3.8 \mathrm{~L} \text { seawater }\end{array}$ & $\begin{array}{l}\text { Flatworm populations exposed } \\
\text { to sunscreen showed a highly } \\
\text { reduced growing rate. Pulse } \\
\text { corals showed effects on } \\
\text { growing rate, with a drastic } \\
\text { decrease during the first week } \\
\text { of treatment and partially } \\
\text { recovering in the following } \\
\text { period, and polyp pulses per } \\
\text { minute, slowed down after } \\
\text { about } 10 \text { min of exposition. All } \\
\text { anemones exposed to } \\
\text { sunscreen were categorized as } \\
\text { unhealthy since pedal disks } \\
\text { were weakly or not attached to } \\
\text { the container walls, tentacles } \\
\text { or body columns were not } \\
\text { extended, individuals did not } \\
\text { clearly respond to touch and } \\
\text { appeared dark brown to black. } \\
\text { Diatoms were less green with } \\
\text { the average green fluorescent } \\
\text { content showing a decrease }\end{array}$ & [36] \\
\hline
\end{tabular}


Table 2. Cont

\begin{tabular}{|c|c|c|c|c|}
\hline UV Filter(s) & Organism(s) & Exposure Conditions & Effects & Reference \\
\hline $\begin{array}{c}\text { BP-3 } \\
\text { HMS } \\
\text { OCS } \\
\text { OCR }\end{array}$ & $\begin{array}{l}\text { Concentrations in water, } \\
\text { sediment, and coral tissue } \\
\text { (Ka'a'awa, Waikiki Beach, } \\
\text { Kaneohe Bay in October } \\
\text { 2017) }\end{array}$ & & $\begin{array}{l}\text { Total mass concentrations of all } \\
\text { UV-filters detected in seawater } \\
\text { were }<750 \mathrm{ng} / \mathrm{L} \text {, in sediment }< \\
70 \mathrm{ng} / \mathrm{g} \text { and in coral tissue }< \\
995 \mathrm{ng} / \mathrm{g} \text { dry weight }(\mathrm{dw}) . \\
\text { UV-filter concentrations } \\
\text { generally varied as follows: } \\
\text { Water: HMS > OCS > BP-3 > } \\
\text { OCR, concentrations in surface } \\
\text { seawater highest at Waikiki } \\
\text { beach; Sediment: HMS > OCS } \\
>\text { OCR > BP-3; } \\
\text { Coral: OCS } \approx \text { HMS }>\text { OCR } \approx \\
\text { BP-3 }\end{array}$ & [94] \\
\hline
\end{tabular}

Legend: benzophenone derivatives (BP-1, BP-3, BP-4, BP-8); octyl methoxycinnamate or ethylhexyl methoxycinnamate (EHMC); octocrylene (OCR); butyl methoxydibenzoylmethane or avobenzone (BMDBM); homosalate (HMS); 4-methylbenzyliden camphor (4-MBC); micrometric zinc oxide (ZnO); ethylhexyl triazone (EHT); terephthalylidene dicamphor sulfonic acid (TDSA); drometrizole trisiloxane (DTS); 2-ethylhexyl 2-cyano-3,3-diphenylacrylate (EHCDA); 2-ethylhexyl salycilate (OCS).

\section{Conclusions}

Although a significant development was reached by global research on the impact of sunscreens and other photoprotective PCPs in nature, much more needs to be understood through future and more in-depth studies. The fields to be explored are many, given the recent interest in this area of environmental toxicology: while studies on nanoparticles in the Mediterranean and on organic UV filters in tropical countries are relatively abundant, ecotoxicological investigations on the average toxicity thresholds are deficient. When assessing the effects on natural coastal environments and coastal biota, we need to take into consideration parameters such as variation in $\mathrm{pH}$, salinity, solar irradiation, level of anthropogenic activities, and currents etc. For example, increasing salinity levels posed a significant risk for the marine copepod Tigropus japonicus in the presence of different concentrations of 4-MBC by exacerbating oxidative stress and the uptake of this chemical [72]. A special focus must be taken to monitor these compounds in natural environments and to evaluate their co-existence in shallow waters as the combination of UV filters and coformulants may enhance or alter the toxic effects of each component. On this matter, a worldwide protocol should be created to make data easily comparable. Important gaps are also related to research on bioaccumulation and biomagnification, of both organic and inorganic UV filters, towards the trophic levels of marine ecological networks.

These new pieces of information will be necessary to improve and integrate the knowledge we have about the environmental effects of sunscreens and allow us to correct our actions and to start empowering institutions and the global population towards a greater respect for the environment. It should be added that, in recent years, we have also seen the first steps in this direction by some tropical countries that care about the fate of the coral reefs along their coasts. For example, the American State of Hawaii applied important restrictions to the ingredients of sunscreen products that can be marketed within their territory to counteract the phenomena of coral bleaching. Moreover, in this case, correct information must be made available to dissuade people from using sunscreens with banned chemicals purchased outside of the State [99] and to reduce misunderstandings on the correct use of sunscreen [100]. Furthermore, special attention needs to be given on Marine Protected Areas [77].

New conservation strategies are needed to drastically reduce the impact on ecosystems [101], possibly developed according to the most vulnerable habitats (e.g., tropical atolls, coral reefs, the Mediterranean coral reef, and other biodiversity hotspots).

Environmental issues are becoming more recognized due to the increasing media coverage provided in this regard, but comprehensive knowledge is lacking. Future leg- 
islation for a "coral safe" labelling might be addressed to help people make informed purchases [99]. By pushing this, initiatives could be promoted to decrease individual impacts on the environment with small gestures that can make a big difference when adopted by many people. For example, reducing the surface of application and the use of opaque garments, such as one-piece swimsuits instead of two-piece swimsuits. The research on new photoprotective compounds, extracted directly from plants, algae and animals, should be encouraged to identify sustainable molecules, easily degradable by organisms. This could be a promising development sector for research institutions and industries working towards a more sustainable future.

Author Contributions: Conceptualization, S.C., T.D., G.F. and L.M.; resources, L.M.; writingoriginal draft preparation, S.C., T.D. and G.F.; writing-review and editing, S.C., T.D., G.F. and L.M.; supervision, L.M. All authors have read and agreed to the published version of the manuscript.

Funding: This research received no external funding.

Conflicts of Interest: The authors declare no conflict of interest.

\section{References}

1. UNEP. Sustainable Coastal Tourism-An Integrated Planning and Management Approach. Available online: https:// wedocs.unep.org/bitstream/handle/20.500.11822/7819/-Sustainable\%20Coastal\%20Tourism\%E2\%80\%94An\%20integrated\% 20planning\%20and\%20management\%20approach-2009913.pdf?sequence=3\&isAllowed=y (accessed on 30 April 2020).

2. Tovar-Sánchez, A.; Sánchez-Quiles, D.; Rodríguez-Romero, A. The mediterranean sea. In Handbook of Environmental Chemistry; Springer: Berlin/Heidelberg, Germany, 2020; Volume 94, pp. 131-161.

3. UNDP. Annual Report; UNDP: New York, NY, USA, 2017.

4. Sánchez-Quiles, D.; Tovar-Sánchez, A. Are sunscreens a new environmental risk associated with coastal tourism? Environ. Int. 2015, 83, 158-170. [CrossRef]

5. Tovar-Sánchez, A.; Sánchez-Quiles, D.; Basterretxea, G.; Benedé, J.L.; Chisvert, A.; Salvador, A.; Moreno-Garrido, I.; Blasco, J. Sunscreen Products as Emerging Pollutants to Coastal Waters. PLoS ONE 2013, 8, e65451. [CrossRef]

6. Giokas, D.L.; Salvador, A.; Chisvert, A. UV filters: From sunscreens to human body and the environment. TrAC Trends Anal. Chem. 2007, 26, 360-374. [CrossRef]

7. Balmer, M.E.; Buser, H.R.; Müller, M.D.; Poiger, T. Occurrence of some organic UV filters in wastewater, in surface waters, and in fish from Swiss lakes. Environ. Sci. Technol. 2005, 39, 953-962. [CrossRef] [PubMed]

8. Amine, H.; Gomez, E.; Halwani, J.; Casellas, C.; Fenet, H. UV filters, ethylhexyl methoxycinnamate, octocrylene and ethylhexyl dimethyl PABA from untreated wastewater in sediment from eastern Mediterranean river transition and coastal zones. Mar. Pollut. Bull. 2012, 64, 2435-2442. [CrossRef] [PubMed]

9. Schneider, S.L.; Lim, H.W. Review of environmental effects of oxybenzone and other sunscreen active ingredients. J. Am. Acad. Dermatol. 2019, 80, 266-271. [CrossRef]

10. Buser, H.R.; Balmer, M.E.; Schmid, P.; Kohler, M. Occurrence of UV filters 4-methylbenzylidene camphor and octocrylene in fish from various Swiss rivers with inputs from wastewater treatment plants. Environ. Sci. Technol. 2006, 40, 1427-1431. [CrossRef] [PubMed]

11. Ramos, S.; Homem, V.; Alves, A.; Santos, L. Advances in analytical methods and occurrence of organic UV-filters in the environment-A review. Sci. Total Environ. 2015, 526, 278-311. [CrossRef] [PubMed]

12. Gago-Ferrero, P.; Díaz-Cruz, M.S.; Barceló, D. An overview of UV-absorbing compounds (organic UV filters) in aquatic biota. Anal. Bioanal. Chem. 2012, 404, 2597-2610. [CrossRef] [PubMed]

13. Danovaro, R.; Bongiorni, L.; Corinaldesi, C.; Giovannelli, D.; Damiani, E.; Astolfi, P.; Greci, L.; Pusceddu, A. Sunscreens cause coral bleaching by promoting viral infections. Environ. Health Perspect. 2008, 116, 441-447. [CrossRef] [PubMed]

14. Labille, J.; Slomberg, D.; Catalano, R.; Robert, S.; Apers-Tremelo, M.L.; Boudenne, J.L.; Manasfi, T.; Radakovitch, O. Assessing UV filter inputs into beach waters during recreational activity: A field study of three French Mediterranean beaches from consumer survey to water analysis. Sci. Total Environ. 2020, 706. [CrossRef]

15. la Farré, M.; Pérez, S.; Kantiani, L.; Barceló, D. Fate and toxicity of emerging pollutants, their metabolites and transformation products in the aquatic environment. TrAC Trends Anal. Chem. 2008, 27, 991-1007. [CrossRef]

16. Sendra, M.; Sánchez-Quiles, D.; Blasco, J.; Moreno-Garrido, I.; Lubián, L.M.; Pérez-García, S.; Tovar-Sánchez, A. Effects of $\mathrm{TiO} 2$ nanoparticles and sunscreens on coastal marine microalgae: Ultraviolet radiation is key variable for toxicity assessment. Environ. Int. 2017, 98, 62-68. [CrossRef] [PubMed]

17. Matranga, V.; Corsi, I. Toxic effects of engineered nanoparticles in the marine environment: Model organisms and molecular approaches. Mar. Environ. Res. 2012, 76, 32-40. [CrossRef] [PubMed]

18. European Council Regulation (EC). No 1223/2009 of the European Parliament and of the Council of 30 November 2009 on Cosmetic Products 1-21. Off. J. Eur. Union 2009, 342, 59-209. 
19. Sánchez-Quiles, D.; Tovar-Sánchez, A. Sunscreens as a source of hydrogen peroxide production in coastal waters. Environ. Sci. Technol. 2014, 48, 9037-9042. [CrossRef]

20. Baek, S.; Joo, S.H.; Blackwelder, P.; Toborek, M. Effects of coating materials on antibacterial properties of industrial and sunscreenderived titanium-dioxide nanoparticles on Escherichia coli. Chemosphere 2018, 208, 196-206. [CrossRef]

21. Botta, C.; Labille, J.; Auffan, M.; Borschneck, D.; Miche, H.; Cabié, M.; Masion, A.; Rose, J.; Bottero, J.Y. TiO 2 -based nanoparticles released in water from commercialized sunscreens in a life-cycle perspective: Structures and quantities. Environ. Pollut. 2011, 159, 1543-1550. [CrossRef]

22. Auffan, M.; Pedeutour, M.; Rose, J.; Masion, A.; Ziarelli, F.; Borschneck, D.; Chaneac, C.; Botta, C.; Chaurand, P.; Labille, J.; et al. Structural degradation at the surface of a $\mathrm{TiO}_{2}$-based nanomaterial used in cosmetics. Environ. Sci. Technol. 2010, 44, 2689-2694. [CrossRef]

23. Tsui, M.M.P.; Leung, H.W.; Wai, T.C.; Yamashita, N.; Taniyasu, S.; Liu, W.; Lam, P.K.S.; Murphy, M.B. Occurrence, distribution and ecological risk assessment of multiple classes of UV filters in surface waters from different countries. Water Res. 2014, 67, 55-65. [CrossRef]

24. Fagervold, S.K.; Rodrigues, A.S.; Rohée, C.; Roe, R.; Bourrain, M.; Stien, D.; Lebaron, P. Occurrence and Environmental Distribution of 5 UV Filters During the Summer Season in Different Water Bodies. Water Air Soil Pollut. 2019, 230, 1-13. [CrossRef]

25. Ma, B.; Lu, G.; Liu, F.; Nie, Y.; Zhang, Z.; Li, Y. Organic UV Filters in the Surface Water of Nanjing, China: Occurrence, Distribution and Ecological Risk Assessment. Bull. Environ. Contam. Toxicol. 2016, 96, 530-535. [CrossRef]

26. Picot-Groz, M.; Fenet, H.; Martinez Bueno, M.J.; Rosain, D.; Gomez, E. Diurnal variations in personal care products in seawater and mussels at three Mediterranean coastal sites. Environ. Sci. Pollut. Res. 2018, 25, 9051-9059. [CrossRef]

27. Tovar-Sanchez, A.; Sparaventi, E.; Gaudron, A.; Rodriguez-Romero, A. A new approach for the determination of sunscreen levels in seawater by ultraviolet absorption spectrophotometry. PLoS ONE 2020, 15, e0243591. [CrossRef] [PubMed]

28. Engel, A.; Bange, H.W.; Cunliffe, M.; Burrows, S.M.; Friedrichs, G.; Galgani, L.; Herrmann, H.; Hertkorn, N.; Johnson, M.; Liss, P.S.; et al. The ocean's vital skin: Toward an integrated understanding of the sea surface microlayer. Front. Mar. Sci. 2017, 4, 1-14. [CrossRef]

29. Allen, J.M.; Gossett, C.J. Photochemical formation of singlet molecular oxygen in illuminated aqueous solutions of several commercially available sunscreen active ingredients. Chem. Res. Toxicol. 1996, 9, 605-609. [CrossRef]

30. Wong, S.W.Y.; Zhou, G.J.; Leung, P.T.Y.; Han, J.; Lee, J.S.; Kwok, K.W.H.; Leung, K.M.Y. Sunscreens containing zinc oxide nanoparticles can trigger oxidative stress and toxicity to the marine copepod Tigriopus japonicus. Mar. Pollut. Bull. 2020, 154, 111078. [CrossRef]

31. Rodríguez-Romero, A.; Ruiz-Gutiérrez, G.; Viguri, J.R.; Tovar-Sánchez, A. Sunscreens as a New Source of Metals and Nutrients to Coastal Waters. Environ. Sci. Technol. 2019, 53, 10177-10187. [CrossRef]

32. Keller, A.A.; Wang, H.; Zhou, D.; Lenihan, H.S.; Cherr, G.; Cardinale, B.J.; Miller, R.; Zhaoxia, J.I. Stability and aggregation of metal oxide nanoparticles in natural aqueous matrices. Environ. Sci. Technol. 2010, 44, 1962-1967. [CrossRef]

33. Thio, B.J.R.; Zhou, D.; Keller, A.A. Influence of natural organic matter on the aggregation and deposition of titanium dioxide nanoparticles. J. Hazard. Mater. 2011, 189, 556-563. [CrossRef] [PubMed]

34. Lewicka, Z.A.; Yu, W.W.; Oliva, B.L.; Contreras, E.Q.; Colvin, V.L. Photochemical behavior of nanoscale $\mathrm{TiO}_{2}$ and $\mathrm{ZnO}$ sunscreen ingredients. J. Photochem. Photobiol. A Chem. 2013, 263, 24-33. [CrossRef]

35. Li, Y.; Yang, D.; Lu, S.; Qiu, X.; Qian, Y.; Li, P. Encapsulating $\mathrm{TiO}_{2}$ in Lignin-Based Colloidal Spheres for High Sunscreen Performance and Weak Photocatalytic Activity. ACS Sustain. Chem. Eng. 2019, 7, 6234-6242. [CrossRef]

36. McCoshum, S.M.; Schlarb, A.M.; Baum, K.A. Direct and indirect effects of sunscreen exposure for reef biota. Hydrobiologia 2016, 776, 139-146. [CrossRef]

37. Inbaraj, J.J.; Bilski, P.; Chignell, C.F. Photophysical and Photochemical Studies of 2-Phenylbenzimidazole and UVB Sunscreen 2-Phenylbenzimidazole-5-sulfonic Acid. Photochem. Photobiol. 2002, 75, 107. [CrossRef]

38. Morel, F.M.M.; Price, N.M. The biogeochemical cycles of trace metals in the oceans. Science 2003, 300, 944-947. [CrossRef] [PubMed]

39. Kotnik, K.; Kosjek, T.; Žegura, B.; Filipič, M.; Heath, E. Photolytic fate and genotoxicity of benzophenone-derived compounds and their photodegradation mixtures in the aqueous environment. Chemosphere 2016, 147, 114-123. [CrossRef] [PubMed]

40. Rodil, R.; Moeder, M.; Altenburger, R.; Schmitt-Jansen, M. Photostability and phytotoxicity of selected sunscreen agents and their degradation mixtures in water. Anal. Bioanal. Chem. 2009, 395, 1513-1524. [CrossRef]

41. MacManus-Spencer, L.A.; Tse, M.L.; Klein, J.L.; Kracunas, A.E. Aqueous photolysis of the organic ultraviolet filter chemical octyl methoxycinnamate. Environ. Sci. Technol. 2011, 45, 3931-3937. [CrossRef] [PubMed]

42. Tovar-Sánchez, A.; Sánchez-Quiles, D.; Rodríguez-Romero, A. Massive coastal tourism influx to the Mediterranean Sea: The environmental risk of sunscreens. Sci. Total Environ. 2019, 656, 316-321. [CrossRef]

43. Paredes, E.; Perez, S.; Rodil, R.; Quintana, J.B.; Beiras, R. Ecotoxicological evaluation of four UV filters using marine organisms from different trophic levels Isochrysis galbana, Mytilus galloprovincialis, Paracentrotus lividus, and Siriella armata. Chemosphere 2014, 104, 44-50. [CrossRef]

44. Canesi, L.; Fabbri, R.; Gallo, G.; Vallotto, D.; Marcomini, A.; Pojana, G. Biomarkers in Mytilus galloprovincialis exposed to

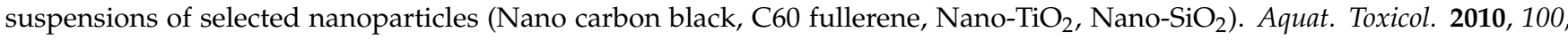
168-177. [CrossRef] 
45. Sureda, A.; Capó, X.; Busquets-Cortés, C.; Tejada, S. Acute exposure to sunscreen containing titanium induces an adaptive response and oxidative stress in Mytillus galloprovincialis. Ecotoxicol. Environ. Saf. 2018, 149, 58-63. [CrossRef] [PubMed]

46. Zhu, X.; Zhou, J.; Cai, Z. The toxicity and oxidative stress of $\mathrm{TiO}_{2}$ nanoparticles in marine abalone (Haliotis diversicolor supertexta). Mar. Pollut. Bull. 2011, 63, 334-338. [CrossRef] [PubMed]

47. Galloway, T.; Lewis, C.; Dolciotti, I.; Johnston, B.D.; Moger, J.; Regoli, F. Sublethal toxicity of nano-titanium dioxide and carbon nanotubes in a sediment dwelling marine polychaete. Environ. Pollut. 2010, 158, 1748-1755. [CrossRef] [PubMed]

48. Manzo, S.; Schiavo, S.; Oliviero, M.; Toscano, A.; Ciaravolo, M.; Cirino, P. Immune and reproductive system impairment in adult sea urchin exposed to nanosized ZnO via food. Sci. Total Environ. 2017, 599-600, 9-13. [CrossRef] [PubMed]

49. Araújo, M.J.; Rocha, R.J.M.; Soares, A.M.V.M.; Benedé, J.L.; Chisvert, A.; Monteiro, M.S. Effects of UV filter 4-methylbenzylidene camphor during early development of Solea senegalensis Kaup, 1858. Sci. Total Environ. 2018, 628-629, 1395-1404. [CrossRef]

50. Liu, H.; Sun, P.; Liu, H.; Yang, S.; Wang, L.; Wang, Z. Acute toxicity of benzophenone-type UV filters for Photobacterium phosphoreum and Daphnia magna: QSAR analysis, interspecies relationship and integrated assessment. Chemosphere 2015, 135, 182-188. [CrossRef]

51. Grabicova, K.; Fedorova, G.; Burkina, V.; Steinbach, C.; Schmidt-Posthaus, H.; Zlabek, V.; Kocour Kroupova, H.; Grabic, R.; Randak, T. Presence of UV filters in surface water and the effects of phenylbenzimidazole sulfonic acid on rainbow trout (Oncorhynchus mykiss) following a chronic toxicity test. Ecotoxicol. Environ. Saf. 2013, 96, 41-47. [CrossRef]

52. Gao, L.; Yuan, T.; Cheng, P.; Zhou, C.; Ao, J.; Wang, W.; Zhang, H. Organic UV filters inhibit multixenobiotic resistance (MXR) activity in Tetrahymena thermophila: Investigations by the Rhodamine 123 accumulation assay and molecular docking. Ecotoxicology 2016, 25, 1318-1326. [CrossRef]

53. Zhang, Q.; Ma, X.; Dzakpasu, M.; Wang, X.C. Evaluation of ecotoxicological effects of benzophenone UV filters: Luminescent bacteria toxicity, genotoxicity and hormonal activity. Ecotoxicol. Environ. Saf. 2017, 142, 338-347. [CrossRef]

54. Mao, F.; He, Y.; Gin, K.Y.H. Evaluating the joint toxicity of two benzophenone-type UV filters on the green alga Chlamydomonas reinhardtii with response surface methodology. Toxics 2018, 6, 8. [CrossRef]

55. Fent, K.; Kunz, P.Y.; Gomez, E. UV filters in the aquatic environment induce hormonal effects and affect fertility and reproduction in fish. Chimia 2008, 62, 368-375. [CrossRef]

56. Blüthgen, N.; Zucchi, S.; Fent, K. Effects of the UV filter benzophenone-3 (oxybenzone) at low concentrations in zebrafish (Danio rerio). Toxicol. Appl. Pharmacol. 2012, 263, 184-194. [CrossRef]

57. Kim, S.; Jung, D.; Kho, Y.; Choi, K. Effects of benzophenone-3 exposure on endocrine disruption and reproduction of japanese medaka (Oryzias latipes)-A two generation exposure study. Aquat. Toxicol. 2014, 155, 244-252. [CrossRef]

58. Kaiser, D.; Sieratowicz, A.; Zielke, H.; Oetken, M.; Hollert, H.; Oehlmann, J. Ecotoxicological effect characterisation of widely used organic UV filters. Environ. Pollut. 2012, 163, 84-90. [CrossRef] [PubMed]

59. Park, C.B.; Jang, J.; Kim, S.; Kim, Y.J. Single- and mixture toxicity of three organic UV-filters, ethylhexyl methoxycinnamate, octocrylene, and avobenzone on Daphnia magna. Ecotoxicol. Environ. Saf. 2017, 137, 57-63. [CrossRef]

60. Cherchi, C.; Gu, A.Z. Impact of titanium dioxide nanomaterials on nitrogen fixation rate and intracellular nitrogen storage in Anabaena variabilis. Environ. Sci. Technol. 2010, 44, 8302-8307. [CrossRef] [PubMed]

61. Jovanović, B.; Whitley, E.M.; Kimura, K.; Crumpton, A.; Palić, D. Titanium dioxide nanoparticles enhance mortality of fish exposed to bacterial pathogens. Environ. Pollut. 2015, 203, 153-164. [CrossRef] [PubMed]

62. Nigro, M.; Bernardeschi, M.; Costagliola, D.; Della Torre, C.; Frenzilli, G.; Guidi, P.; Lucchesi, P.; Mottola, F.; Santonastaso, M.; Scarcelli, V.; et al. $\mathrm{n}-\mathrm{TiO}_{2}$ and $\mathrm{CdCl}_{2}$ co-exposure to titanium dioxide nanoparticles and cadmium: Genomic, DNA and chromosomal damage evaluation in the marine fish European sea bass (Dicentrarchus labrax). Aquat. Toxicol. 2015, 168, 72-77. [CrossRef]

63. Xia, B.; Zhu, L.; Han, Q.; Sun, X.; Chen, B.; Qu, K. Effects of $\mathrm{TiO}_{2}$ nanoparticles at predicted environmental relevant concentration on the marine scallop Chlamys farreri: An integrated biomarker approach. Environ. Toxicol. Pharmacol. 2017, 50, 128-135. [CrossRef]

64. Miller, R.J.; Lenihan, H.S.; Muller, E.B.; Tseng, N.; Hanna, S.K.; Keller, A.A. Impacts of metal oxide nanoparticles on marine phytoplankton. Environ. Sci. Technol. 2010, 44, 7329-7334. [CrossRef] [PubMed]

65. Peng, X.; Palma, S.; Fisher, N.S.; Wong, S.S. Effect of morphology of ZnO nanostructures on their toxicity to marine algae. Aquat. Toxicol. 2011, 102, 186-196. [CrossRef]

66. Wong, S.W.Y.; Leung, P.T.Y.; Djurišić, A.B.; Leung, K.M.Y. Toxicities of nano zinc oxide to five marine organisms: Influences of aggregate size and ion solubility. Anal. Bioanal. Chem. 2010, 396, 609-618. [CrossRef] [PubMed]

67. Schiavo, S.; Oliviero, M.; Li, J.; Manzo, S. Testing ZnO nanoparticle ecotoxicity: Linking time variable exposure to effects on different marine model organisms. Environ. Sci. Pollut. Res. 2018, 25, 4871-4880. [CrossRef] [PubMed]

68. Giraldo, A.; Montes, R.; Rodil, R.; Quintana, J.B.; Vidal-Liñán, L.; Beiras, R. Ecotoxicological Evaluation of the UV Filters Ethylhexyl Dimethyl p-Aminobenzoic Acid and Octocrylene Using Marine Organisms Isochrysis galbana, Mytilus galloprovincialis and Paracentrotus lividus. Arch. Environ. Contam. Toxicol. 2017, 72, 606-611. [CrossRef]

69. Barmo, C.; Ciacci, C.; Canonico, B.; Fabbri, R.; Cortese, K.; Balbi, T.; Marcomini, A.; Pojana, G.; Gallo, G.; Canesi, L. In vivo effects of $\mathrm{n}-\mathrm{TiO}_{2}$ on digestive gland and immune function of the marine bivalve Mytilus galloprovincialis. Aquat. Toxicol. 2013, 132-133, 9-18. [CrossRef] 
70. Barone, A.N.; Hayes, C.E.; Kerr, J.J.; Lee, R.C.; Flaherty, D.B. Acute toxicity testing of $\mathrm{TiO}_{2}$-based vs. oxybenzone-based sunscreens on clownfish (Amphiprion ocellaris). Environ. Sci. Pollut. Res. 2019, 14513-14520. [CrossRef] [PubMed]

71. Santonocito, M.; Salerno, B.; Trombini, C.; Tonini, F.; Pintado-Herrera, M.G.; Martínez-Rodríguez, G.; Blasco, J.; Lara-Martín, P.A.; Hampel, M. Stress under the sun: Effects of exposure to low concentrations of UV-filter 4-methylbenzylidene camphor (4-MBC) in a marine bivalve filter feeder, the Manila clam Ruditapes philippinarum. Aquat. Toxicol. 2020, 221. [CrossRef]

72. Hong, H.; Wang, J.; Shi, D. Effects of salinity on the chronic toxicity of 4-methylbenzylidene camphor (4-MBC) in the marine copepod Tigriopus japonicus. Aquat. Toxicol. 2021, 232, 105742. [CrossRef] [PubMed]

73. Thorel, E.; Clergeaud, F.; Jaugeon, L.; Rodrigues, A.M.S.; Lucas, J.; Stien, D.; Lebaron, P. Effect of 10 UV filters on the brine shrimp Artemia salina and themarinemicroalga Tetraselmis sp. Toxics 2020, 8, 29. [CrossRef]

74. Bachelot, M.; Li, Z.; Munaron, D.; Le Gall, P.; Casellas, C.; Fenet, H.; Gomez, E. Organic UV filter concentrations in marine mussels from French coastal regions. Sci. Total Environ. 2012, 420, 273-279. [CrossRef]

75. Sang, Z.; Leung, K.S.Y. Environmental occurrence and ecological risk assessment of organic UV filters in marine organisms from Hong Kong coastal waters. Sci. Total Environ. 2016, 566-567, 489-498. [CrossRef]

76. Amine, H.; Gomez, E.; Halwani, J.; Casellas, C.; Fenet, H.; Araújo, M.J.; Rocha, R.J.M.; Soares, A.M.V.M.; Benedé, J.L.; Chisvert, A.; et al. Photostability and phytotoxicity of selected sunscreen agents and their degradation mixtures in water. Sci. Total Environ. 2018, 25, 368-375. [CrossRef]

77. Moschino, V.; Schintu, M.; Marrucci, A.; Marras, B.; Nesto, N.; Da Ros, L. An ecotoxicological approach to evaluate the effects of tourism impacts in the Marine Protected Area of La Maddalena (Sardinia, Italy). Mar. Pollut. Bull. 2017, 122, 306-315. [CrossRef] [PubMed]

78. Kunz, P.Y.; Fent, K. Estrogenic activity of UV filter mixtures. Toxicol. Appl. Pharmacol. 2006, 217, 86-99. [CrossRef] [PubMed]

79. Lorigo, M.; Mariana, M.; Cairrao, E. Photoprotection of ultraviolet-B filters: Updated review of endocrine disrupting properties. Steroids 2018, 131, 46-58. [CrossRef] [PubMed]

80. Silvia Díaz-Cruz, M.; Llorca, M.; Barceló, D. Organic UV filters and their photodegradates, metabolites and disinfection byproducts in the aquatic environment. TrAC Trends Anal. Chem. 2008, 27, 873-887. [CrossRef]

81. Gago-Ferrero, P.; Alonso, M.B.; Bertozzi, C.P.; Marigo, J.; Barbosa, L.; Cremer, M.; Secchi, E.R.; Azevedo, A.; Lailson-Brito, J.; Torres, J.P.M.; et al. First determination of UV filters in marine mammals. octocrylene levels in Franciscana dolphins. Environ. Sci. Technol. 2013, 47, 5619-5625. [CrossRef]

82. He, K.; Hain, E.; Timm, A.; Blaney, L. Bioaccumulation of estrogenic hormones and UV-filters in red swamp crayfish (Procambarus clarkii). Sci. Total Environ. 2021, 764, 142871. [CrossRef]

83. Molins-Delgado, D.; Muñoz, R.; Nogueira, S.; Alonso, M.B.; Torres, J.P.; Malm, O.; Ziolli, R.L.; Hauser-Davis, R.A.; Eljarrat, E.; Barceló, D.; et al. Occurrence of organic UV filters and metabolites in lebranche mullet (Mugil liza) from Brazil. Sci. Total Environ. 2018, 618, 451-459. [CrossRef]

84. Zenker, A.; Schmutz, H.; Fent, K. Simultaneous trace determination of nine organic UV-absorbing compounds (UV filters) in environmental samples. J. Chromatogr. A 2008, 1202, 64-74. [CrossRef]

85. Baker, T.J.; Tyler, C.R.; Galloway, T.S. Impacts of metal and metal oxide nanoparticles on marine organisms. Environ. Pollut. 2014, 186, 257-271. [CrossRef]

86. Chen, J.; Li, H.; Han, X.; Wei, X. Transmission and Accumulation of Nano-TiO 2 in a 2-Step Food Chain (Scenedesmus obliquus to Daphnia magna). Bull. Environ. Contam. Toxicol. 2015, 95, 145-149. [CrossRef] [PubMed]

87. Wang, Z.; Yin, L.; Zhao, J.; Xing, B. Trophic transfer and accumulation of $\mathrm{TiO}_{2}$ nanoparticles from clamworm (Perinereis aibuhitensis) to juvenile turbot (Scophthalmus maximus) along a marine benthic food chain. Water Res. 2016, 95, 250-259. [CrossRef]

88. Della Torre, C.; Buonocore, F.; Frenzilli, G.; Corsolini, S.; Brunelli, A.; Guidi, P.; Kocan, A.; Mariottini, M.; Mottola, F.; Nigro, M.; et al. Influence of titanium dioxide nanoparticles on 2,3,7,8-tetrachlorodibenzo-p-dioxin bioconcentration and toxicity in the marine fish European sea bass (Dicentrarchus labrax). Environ. Pollut. 2015, 196, 185-193. [CrossRef] [PubMed]

89. Hou, J.; Wu, Y.; Li, X.; Wei, B.; Li, S.; Wang, X. Toxic effects of different types of zinc oxide nanoparticles on algae, plants, invertebrates, vertebrates and microorganisms. Chemosphere 2018, 193, 852-860. [CrossRef]

90. De Schamphelaere, K.A.C.; Canli, M.; Van Lierde, V.; Forrez, I.; Vanhaecke, F.; Janssen, C.R. Reproductive toxicity of dietary zinc to Daphnia magna. Aquat. Toxicol. 2004, 70, 233-244. [CrossRef]

91. Danovaro, R.; Armeni, M.; Corinaldesi, C.; Mei, M.L. Viruses and marine pollution. Mar. Pollut. Bull. 2003, 46, 301-304. [CrossRef]

92. He, T.; Tsui, M.M.P.; Tan, C.J.; Ng, K.Y.; Guo, F.W.; Wang, L.H.; Chen, T.H.; Fan, T.Y.; Lam, P.K.S.; Murphy, M.B. Comparative toxicities of four benzophenone ultraviolet filters to two life stages of two coral species. Sci. Total Environ. 2019, 651, 2391-2399. [CrossRef]

93. Tsui, M.M.P.; Lam, J.C.W.; Ng, T.Y.; Ang, P.O.; Murphy, M.B.; Lam, P.K.S. Occurrence, Distribution, and Fate of Organic UV Filters in Coral Communities. Environ. Sci. Technol. 2017, 51, 4182-4190. [CrossRef]

94. Mitchelmore, C.L.; He, K.; Gonsior, M.; Hain, E.; Heyes, A.; Clark, C.; Younger, R.; Schmitt-Kopplin, P.; Feerick, A.; Conway, A.; et al. Occurrence and distribution of UV-filters and other anthropogenic contaminants in coastal surface water, sediment, and coral tissue from Hawaii. Sci. Total Environ. 2019, 670, 398-410. [CrossRef]

95. Brausch, J.M.; Rand, G.M. A review of personal care products in the aquatic environment: Environmental concentrations and toxicity. Chemosphere 2011, 82, 1518-1532. [CrossRef] 
96. Downs, C.A.; Kramarsky-Winter, E.; Segal, R.; Fauth, J.; Knutson, S.; Bronstein, O.; Ciner, F.R.; Jeger, R.; Lichtenfeld, Y.; Woodley, C.M.; et al. Toxicopathological Effects of the Sunscreen UV Filter, Oxybenzone (Benzophenone-3), on Coral Planulae and Cultured Primary Cells and Its Environmental Contamination in Hawaii and the U.S. Virgin Islands. Arch. Environ. Contam. Toxicol. 2016, 70, 265-288. [CrossRef]

97. Corinaldesi, C.; Marcellini, F.; Nepote, E.; Damiani, E.; Danovaro, R. Impact of inorganic UV filters contained in sunscreen products on tropical stony corals (Acropora spp.). Sci. Total Environ. 2018, 637-638, 1279-1285. [CrossRef]

98. Fel, J.P.; Lacherez, C.; Bensetra, A.; Mezzache, S.; Béraud, E.; Léonard, M.; Allemand, D.; Ferrier-Pagès, C. Photochemical response of the scleractinian coral Stylophora pistillata to some sunscreen ingredients. Coral Reefs 2019, 38, 109-122. [CrossRef]

99. Levine, A. Sunscreen use and awareness of chemical toxicity among beach goers in Hawaii prior to a ban on the sale of sunscreens containing ingredients found to be toxic to coral reef ecosystems. Mar. Policy 2020, 103875. [CrossRef]

100. Sirois, J. Examine all available evidence before making decisions on sunscreen ingredient bans. Sci. Total Environ. 2019, 674, 211-212. [CrossRef] [PubMed]

101. Corinaldesi, C.; Damiani, E.; Marcellini, F.; Falugi, C.; Tiano, L.; Brugè, F.; Danovaro, R. Sunscreen products impair the early developmental stages of the sea urchin Paracentrotus lividus. Sci. Rep. 2017, 7, 7815. [CrossRef] [PubMed] 